\title{
Physicochemical characterization of honey from different regions in Rio Grande do Sul State labeled with different inspection service stamps
}

\author{
Caracterização físico-química de méis de diferentes localidades do Rio Grande do Sul com diferentes \\ selos de serviços de inspeção
}

\author{
Ludmila Noskoski Salazar ${ }^{1}$, Ana Beatriz Benevides de Freitas ${ }^{2}$, Mariela Valério da Luz ${ }^{3}$, Patrícia Bersch ${ }^{4}$, Rodrigo \\ Fernando dos Santos Salazar ${ }^{5}$
}

${ }^{1}$ Profa'. Adjunta I. Medicina Veterinária. Centro de Ciências da Saúde e Agrárias (CCSA) - UNICRUZ, Cruz Alta - RS, Brasil lnoskoski@unicruz.edu.br

${ }^{2}$ Residente em Medicina Preventiva, Análises Micotoxicológicas e Patologia Aviária. Programa de Residência Multiprofissional Integrada em Sistema Público de Saúde - UFSM, Santa Maria - RS, Brasil ana.beatriz.benevides@hotmail.com

${ }^{3}$ Acadêmica do Curso de Medicina Veterinária. Centro de Ciências da Saúde e Agrárias (CCSA) - UNICRUZ, Cruz Alta - RS, Brasil marylelaluz@hotmail.com

${ }^{4}$ Prof ${ }^{\mathrm{a}}$ Assistente I. Engenharia Civil, Centro de Ciências Humanas e Sociais (CCHS) - UNICRUZ, Cruz Alta - RS, Brasil pbersch@unicruz.edu.br

${ }^{5}$ Prof. Titular I. Programa de Pós-Graduação Stricto Sensu em Atenção Integral à Saúde (PPGAIS) - UNICRUZ/UNIJUI, Cruz Alta - RS, Brasil rsalazar@unicruz.edu.br

\section{Resumo}

O mel é um produto com elevado valor nutritivo e propriedades terapêuticas. Entretanto, pode apresentar diferentes defeitos decorrentes do mal processamento ou fraudes, necessitando de rigoroso controle de qualidade e fiscalização em toda cadeia produtiva. Neste sentido, avaliou-se a qualidade fisico-química de méis de diferentes localidades do Rio Grande do Sul. A amostragem consistiu de 12 lotes de méis de 12 fabricantes distintos entre cooperativas e industriais. Foram determinados a acidez ( $\left.\mathrm{mEq} \mathrm{kg}^{-1}\right)$; cinzas (\% $\left./ \mathrm{m}\right)$; corantes (qualitativo); pH; reação de Fiehe (qualitativo); reação de Lugol (qualitativo); reação de Lund $(\mathrm{mL})$ e umidade $(\%$ m/v). Empregou-se os protocolos padronizados da Association of Official Analytical Chemists (AOAC) para as determinações analiticas. As amostras apresentaram teores de umidade, cinzas, pH, acidez e a reação de Lund em torno de $18,88 \pm 5,5 \% \mathrm{~m} / \mathrm{v}, 0,040 \pm 0,014 \% \mathrm{~m} / \mathrm{m}, 4,23 \pm 0,19 ; 25,28 \pm 8,95 \mathrm{mEq} \mathrm{kg}{ }^{-1}$ e $1,92 \pm 0,60 \mathrm{~mL}$, respectivamente. As amostras deram negativo para o teste de deteç̧ão de corantes, para reação de Lugol e Reação de Fiehe. Por fim, Verificou-se a boa procedência dos méis, remetendo às boas práticas de fabricação que tangem os apicultores até as cooperativas e industriais envolvidas no acabamento final dos méis comercializados, independentemente do selo de inspeção.

Palavras-chave: Controle de qualidade. Inspeção. Segurança Alimentar.

\begin{abstract}
Honey is a food of high nutritional value and therapeutic properties; however, it may present different non-conformities due to poor processing or fraud. Therefore, the honey production chain requires strict quality control and inspection. Accordingly, the physicochemical quality of honey from different agribusinesses in Rio Grande do Sul State was herein assessed. The sample consisted of 12 honey types from 12 different cooperatives and manufacturers. Honey acidity ( $\left.\mathrm{mEq} \mathrm{kg}^{-1}\right)$, Ash (\% $\%_{\mathrm{m} / \mathrm{m}}$ ), Dyes (qualitative), $\mathrm{pH}$, Fiehe reaction (qualitative), Lugol reaction (qualitative), Lund reaction $(\mathrm{mL})$ and humidity $\left(\%_{\mathrm{m} / \mathrm{v}}\right)$ were found. The standard protocols set by the Association of Official Analytical Chemists (AOAC) were used for analytical purposes. The samples presented moisture content, ash, $\mathrm{pH}$, acidity and Lund's reaction of approximately $18.88 \pm 5.5 \% \mathrm{~m} / \mathrm{v}, 0.040 \pm 0.014 \% \mathrm{~m} / \mathrm{m}$, 4.23 $\pm 0.19 ; 25.28 \pm 8.95 \mathrm{mEq} \mathrm{kg} \mathrm{and}^{-1}$ an $\pm 0.60 \mathrm{~mL}$, respectively. They presented negative results in the dye detection test, and in the Lugol and Fiehe reactions. Furthermore, the food safety of the assessed honey types was checked and the results showed that good manufacturing practices affect the beekeepers in the cooperatives and production plants involved in the final commercial honey production, regardless of the inspection stamp.
\end{abstract}

Keywords: Food inspection. Quality control. Food safety. 


\section{Introduction}

Honey is a food of animal origin widely appreciated in different cultures due to its high nutritional value, characteristic flavor and therapeutic properties; besides, it is used as natural sweetener and energy source because of its medicinal importance (AROUCHA, 2008; JATI, 2007; RICHTER, 2011; BULIGNOL et al, 2016). According to the Brazilian Administration of Agriculture, Livestock and Food Supply, also known as MAPA, honey is the food produced by honeybees who collect flower nectar or the secretion from plant living-parts, or even the excretion from plant-sucking insects to be their raw material. These nectars, secretions and excretions lie on plant living-parts, and the bees collect, transform, and combine them with specific substances from the bees' themselves; next, they store and let the mixture ripe in the hive combs (MAPA, 2000). Honey chemical composition comprises different sugars, mainly monosaccharides such as glucose and fructose. In addition, it is possible finding levels of proteins, amino acids, enzymes, organic acids, mineral substances, pollen and other substances in it (RICHTER, 2011; BULIGNOL et al, 2016). Some polysaccharides such as sucrose, maltose, malaise, and dextrin are components commonly found in honey, regardless of the flowering or bee species (JATI, 2007). Other honey components found in small concentrations are fungi, algae, yeasts and other solid particles resulting from its production process (CODEX ALIMENTARIUS, 2001).

Different honey types usually come from different flowering plants; however, eucalyptus and citrus flowers, as well as wildflowers are the most used in large-scale honey production and trade (AIDAR, 1997). It is common finding different physical and chemical compositions depending on the honey type, because several factors, such as climatic conditions, maturation phase, bee species and flowering type, (PÉREZ et al., 2007), as well as product processing and storage (AROUCHA et al, 2008) influence its quality. However, according to the current legislation, honey cannot comprise sugars and/or other substances because they change its composition (MAPA, 2000).

The Brazilian Administration of Agriculture, Livestock and Food Supply (MAPA) implemented the "Technical Regulation on Honey Identity and Quality" through Normative Instruction N. 11 from October $20^{\text {th }}$, which sets the quality standards and the identity of the honey in order to assure the quality of the product sold throughout the country. The Normative Instruction also establishes the acceptable incidence levels of certain physicochemical components, the sensorial attributes and the microbiological parameters that may be present or absent in honey. These levels are set in order to allow honey processing and trading without any food-safety or health damage risk (MAPA, 2000).

Among the main adulterations made in honey, it is possible mentioning the addition of commercial sugars, glucose, molasses and inverted sugar solution (RYBAK-CHMIELEWSKA, 2003); these changes are often practiced during processing (filtration, centrifugation and decantation) (AROUCHA et al, 2008). Besides these changes, natural modifications resulting from excessive moisture, heat or aging may also occur (RICHTER, 2011). Accordingly, the quality control achieved through the physical and chemical tests applied to honey contributes to the inspection of the commercialized product and to the quality control of internally produced honey throughout the extraction, processing and commercialization stages (CRANE, 1985; CAMARGO et al, 2003; NUNES, 2005; WELKE et al, 2008). The test results are compared to the standards set by the official international bodies or to the national standards as a way to protect consumers from acquiring an adulterated product (MARCHINI, 2004; RICHTER, 2011).

According to MAPA (2000), the physicochemical analyses indicated for pure Apis honey quality control are divided in four subgroups: i) maturity (reducing sugars, moisture, apparent sucrose); ii) purity (solids insoluble in water, minerals or ash, pollen); iii) and degree of deterioration (free acidity, diastase activity and hydroxymethylfurfural HMF) (MAPA, 2000). Therefore, we sought to assess the physicochemical attributes, purity and degree of deterioration 
of different honey brands sold in Rio Grande do Sul State, Southern Brazil, in order to check these honey types quality and adequacy to the Brazilian legislation standards.

\section{Material and methods}

Sampling

The honey sample comprised different brands from different rural districts and colonial fairs from nine locations in Rio Grande do Sul State. Producers and manufacturers' names were kept secret and codified (Table 1). All the purchased samples were kept in their selling packages and sent to the laboratory of General Chemistry at Cruz Alta University.

Table 1 - Batch description based on city of origin, location (latitude and longitude), inspection stamp (SIM, CISPOA or SIF), flowering type

\begin{tabular}{c|c|c|c|c}
\hline \multirow{2}{*}{ Sample } & \multirow{2}{*}{ City } & \multicolumn{2}{|c|}{ Geographical coordinates } & \multirow{2}{*}{ Flowering } \\
\cline { 2 - 4 } & Cambará do Sul - RS & $29^{\circ} 02^{\prime} 52^{\prime \prime} \mathrm{S}$ & $50^{\circ} 08^{\prime} 42^{\prime \prime} \mathrm{W}$ & Sylvan \\
\hline $\mathbf{n}$ & Cambará do Sul - RS & $29^{\circ} 02^{\prime} 52^{\prime \prime} \mathrm{S}$ & $50^{\circ} 08^{\prime} 42^{\prime \prime} \mathrm{W}$ & Eucalyptus \\
\hline $\mathbf{2}$ & Içara - SC & $28^{\circ} 42^{\prime} 48^{\prime \prime} \mathrm{S}$ & $49^{\circ} 18^{\prime} 00^{\prime \prime} \mathrm{W}$ & Sylvan (Organic) \\
\hline $\mathbf{4}$ & Prudentópolis - PR & $25^{\circ} 12^{\prime} 46^{\prime \prime} \mathrm{S}$ & $50^{\circ} 58^{\prime} 40^{\prime \prime} \mathrm{W}$ & Sylvan \\
\hline $\mathbf{5}$ & Guarapuava - PR & $25^{\circ} 23^{\prime} 42^{\prime \prime} \mathrm{S}$ & $51^{\circ} 27^{\prime} 28^{\prime \prime} \mathrm{W}$ & CiF \\
\hline $\mathbf{6}$ & Xaxim - SC & $26^{\circ} 57^{\prime} 42^{\prime \prime} \mathrm{S}$ & $52^{\circ} 32^{\prime} 05^{\prime \prime} \mathrm{W}$ & SIF \\
\hline $\mathbf{8}$ & Porto Alegre - RS & $30^{\circ} 01^{\prime} 58^{\prime \prime} \mathrm{S}$ & $51^{\circ} 13^{\prime} 48^{\prime \prime} \mathrm{W}$ & Sylvan \\
\hline $\mathbf{9}$ & Caçapava do Sul - RS & $30^{\circ} 30^{\prime} 43^{\prime \prime} \mathrm{S}$ & $53^{\circ} 29^{\prime} 27^{\prime \prime} \mathrm{W}$ & Citrus \\
\hline
\end{tabular}

* Cispoa: Coordination of Animal Origin Product Sanitary Inspection; SIF: Federal Inspection Service; SIM: Municipal Inspection Service

In addition to the samples from different cities in Rio Grande do Sul State, the choice was made to assess up to two honey types from Paraná and Santa Catarina states in order to compare them to data of the honey produced in Rio Grande do Sul State apiaries. Furthermore, the present study also had the aim of investigating whether the nature of the flowering and the inspection service stamps are possible parameters to be used in honey physicochemical quality differentiation.

The procedures suggested by Nunes (2005) were followed for sample conservation until the moment to perform the analyses. The room temperature faced approximately $25{ }^{\circ} \mathrm{C}$ oscillation throughout the analyses. The physicochemical tests were performed according to the methodological procedures proposed by the National Animal Reference Laboratory (LANARA, 1981) and by Zenebon et al. (2008). The determination in each parameter was conducted in quintuplicate per sample $(\mathrm{n}=5)$. 
Reagents and solutions

The reagents used in the present study were of analytical grade. Distilled and deionized water were used to clean and prepare the solutions, respectively. The flasks, glassware and polypropylene materials were washed and soaked in $10 \% \mathrm{v}_{\mathrm{v} / \mathrm{v}} \mathrm{HNO}_{3}$, and thoroughly washed in deionized water to avoid contamination.

\section{Analytical procedures}

Moisture, ash content, $\mathrm{pH}$ determination, acidity, Lugol reaction, Fiehe reaction, and Lund reaction analyses, and dye research were performed. The results were compared to the recommendations of the Brazilian Administration of Agriculture, Livestock and Food Supply (MAPA, 2000).

The moisture analysis was performed according to the techniques described by the National Animal Reference Laboratory (LANARA, 1981). Refractometry was the method of choice, and its interpretation was based on the Chataway table using the Quimis ${ }^{\circledR}$ refractometer. One drop of honey was placed on a specific position in the refractometer for sample reading. The reading based on the Brix scale was adapted according to the Chataway table.

The ash content analysis was performed according to the techniques described by LANARA (1981). Two grams of sample were weighed in a porcelain crucible, preheated in a muffle oven for 30 minutes, cooled in a desiccator using silica gel and weighed again. The sample was charred in a Bunssen's beaker and, then, transferred to a muffle furnace at $600{ }^{\circ} \mathrm{C}$. White ash calcination was performed by leaving the sample for 4 hours inside the muffle oven. Next, the sample was cooled in a desiccator and weighed again. The procedure was repeated for one more hour, until the weight became constant. Calculations were made by applying equation 1 , wherein $\mathrm{P}$ is the ash mass $(\mathrm{g})$ and $\mathrm{P}^{\prime}$ is the total mass of the sample $(\mathrm{g})$ before calcination, and Ash $(\% \mathrm{~m} / \mathrm{m})$ is the percentage of ash content in the honey sample.

$$
\operatorname{Ash}_{(\% m / m)}=\left(\frac{P}{P^{\prime}}\right) \cdot 100
$$

The $\mathrm{pH}$ determination was performed according to the techniques described by LANARA (1981). Ten grams (10.0 g) of honey were weighed in an analytical scale and diluted in $75.0 \mathrm{~mL}$ of distilled water; the sample was then read using a pHmeter.

The acidity analysis was performed according to the techniques described by LANARA (ANIMAL, 1981). The honey solution prepared for $\mathrm{pH}$ determination and titrated with $0.1 \mathrm{~N}$ sodium hydroxide solution was used to reach the turning point of the indicator and to record the spent volume. Calculations were made by means of equation 2 , wherein $\mathrm{V}$ is the consumed $\mathrm{NaOH}$ volume $(\mathrm{mL})$ and $\mathrm{f}$ is the analytical-standard correction factor; acidity was reported through $\mathrm{mEq} / \mathrm{kg}$ of honey:

$$
\operatorname{Acidity}_{(\mathrm{mEq} / \mathrm{kg})}=V . f .10
$$

The reaction using the Lugol's solution was adopted to investigate starch and dextrin presence in the honey. The investigation was performed according to the techniques described by Zenebon et al. (2008), ten grams (10.0 g) of sample were weighed in a $50 \mathrm{~mL}$ beaker; next, $20 \mathrm{~mL}$ of water were added to it and the sample was homogenized. The 
sample was kept in boiling water for 1 hour and, subsequently, left to cool down to room temperature; $0.5 \mathrm{~mL}$ of the Lugol solution was added to the sample after heating. The solution turned from reddish-brown to blue in the presence of commercial glucose or sugar syrups. The color intensity depends on the quality and quantity of dextrin or of the starch found in the adulterated sample.

The qualitative evidence of hydroxymethylfurfural (HMF), or Fiehe reaction, was performed according to the techniques described by LANARA (1981). In order to proceed with the method, $10 \mathrm{~mL}$ of $50 \% \%_{\mathrm{v} / \mathrm{v}}$ honey solution were stirred in a test tube containing $5 \mathrm{~mL}$ of ethyl ether. The sample was allowed to rest until the ethereal layer became clear. Then, $2 \mathrm{~mL}$ of the ether layer was transferred to another test tube containing 5 drops of fresh $1 \%$ resorcinol solution in concentrated $\mathrm{HCl}$. The sample was stirred again and the staining that acquired the resorcinol drops at the bottom of the test tube was observed. If the immediate cherry-red or salmon color showed up, it would indicate the presence of invert sugar caused by the acid treatment, as well as by the intense heating or prolonged storage at high room temperature (CRANE, 1985; CAMARGO et al., 2003; NUNES, 2005).

The Lund reaction is applicable to honey samples and it indicates the presence of albuminous cells; however, its absence indicates fraud. This reaction was performed according to the techniques described by Zenebon and collaborators (2008). Two grams ( $2.0 \mathrm{~g})$ of the sample were weighed, transferred to a $50.0-\mathrm{mL}$ beaker and added with $20.0 \mathrm{~mL}$ of water and $5 \mathrm{~mL}$ of $0.5 \% \mathrm{v} / \mathrm{v}$ tannic acid solution. Thereafter, water was added until reaching the total volume $40.0 \mathrm{~mL}$, and stirred for complete mixing. The sample was once more allowed to rest for 24 hours. A precipitate (0.6 to $3.0 \mathrm{~mL}$ ) forms at the bottom of the beaker in the presence of pure honey. The precipitate shall not form or exceed the aforementioned maximum volume range in the presence of adulterated honey (CAMARGO et al, 2003; ZENEBON et al, 2008).

The dye research was performed according to the techniques described by the Brazilian Society of Pharmacognosy (SBF, 2016). One gram (1.0 g) of honey was weighed and dissolved in $10.0 \mathrm{ml}$ of distilled water. Approximately $2.0 \mathrm{~mL}$ of $5 \% \mathrm{w} / \mathrm{v}$ sulfuric acid solution was added to the diluted-honey sample. The honey should remain unchanged according to the analysis protocol (SBF, 2016). When coloring substances are added to the honey, the color gradually changes from violet to pink (CRANE, 1985; CAMARGO et al, 2003; NUNES, 2005).

\section{Results and discussion}

Initially, the physicochemical quality of the assessed honey types showed no differences resulting from state of origin (Paraná, Rio Grande do Sul or Santa Catarina), inspection stamp (Municipal Inspection Service - SIM; Coordination of Industrial and Sanitary Inspection of Products of Animal Origin - Cispoa; Federal Inspection Service SIF) or flowering (citrus, eucalyptus or sylvan). The only difference between samples concerned the physicochemical properties. The moisture, ash content, $\mathrm{pH}$, acidity, Lugol reaction, Fiehe reaction, and Lund reaction analysis results, as well as the dye research of the different honey samples are shown in Table 2. 
Table 2 - Physicochemical parameters determined to honey samples. Values are represented by the mean and the standard deviation $(n=5)$

\begin{tabular}{|c|c|c|c|c|c|c|c|c|}
\hline Sample & $\begin{array}{c}\text { Moisture } \\
\left(\% \%_{m / v}\right)\end{array}$ & $\operatorname{Ash}\left(\%_{m / m}\right)$ & pH & $\begin{array}{c}\text { Acidity } \\
(\mathrm{mEq} / \mathrm{kg})\end{array}$ & $\begin{array}{c}\text { Lugol } \\
\text { reaction* }\end{array}$ & $\begin{array}{c}\text { Fiehe } \\
\text { reaction* }\end{array}$ & $\begin{array}{c}\text { Lund } \\
\text { reaction }(\mathrm{mL})\end{array}$ & Dyestuff* \\
\hline 1 & $18.27 \pm 0.91$ & $0.055 \pm 0.014$ & $4.16 \pm 0.21$ & $23.04 \pm 1.04$ & $\mathrm{~N}$ & $\mathrm{~N}$ & $2.0 \pm 0.1$ & $\mathrm{~N}$ \\
\hline 2 & $16.80 \pm 0.75$ & $0.046 \pm 0.002$ & $4.14 \pm 0.20$ & $21.12 \pm 0.74$ & $\mathrm{~N}$ & $\mathrm{~N}$ & $2.5 \pm 0.2$ & $\mathrm{~N}$ \\
\hline 3 & $21.18 \pm 1.36$ & $0.029 \pm 0.003$ & $4.20 \pm 0.14$ & $40.32 \pm 2.42$ & $\mathrm{~N}$ & $\mathrm{~N}$ & $1.5 \pm 0.1$ & $\mathrm{~N}$ \\
\hline 4 & $6.62 \pm 0.13$ & $0.003 \pm 0.001$ & $4.55 \pm 0.13$ & $21.12 \pm 1.48$ & $\mathrm{~N}$ & $\mathrm{~N}$ & $1.5 \pm 0.1$ & $\mathrm{~N}$ \\
\hline 5 & $24.6 \pm 1.46$ & $0.002 \pm 0.001$ & $4.39 \pm 0.25$ & $27.84 \pm 1.50$ & $\mathrm{~N}$ & $\mathrm{~N}$ & $2.5 \pm 0.3$ & $\mathrm{~N}$ \\
\hline 6 & $19.13 \pm 0.48$ & $0.005 \pm 0.002$ & $4.4 \pm 0.23$ & $11.52 \pm 0.58$ & $\mathrm{~N}$ & $\mathrm{~N}$ & $1.0 \pm 0.2$ & $\mathrm{~N}$ \\
\hline 7 & $19.72 \pm 1.06$ & $0.008 \pm 0.002$ & $3.96 \pm 0.15$ & $30.72 \pm 1.98$ & $\mathrm{~N}$ & $\mathrm{P}$ & $2.0 \pm 0.1$ & $\mathrm{~N}$ \\
\hline 8 & $24.01 \pm 1.44$ & $0.170 \pm 0.032$ & $4.0 \pm 0.12$ & $34.56 \pm 1.56$ & $\mathrm{~N}$ & $\mathrm{~N}$ & $1.5 \pm 0.3$ & $\mathrm{~N}$ \\
\hline 9 & $19.63 \pm 0.69$ & $0.012 \pm 0.004$ & $4.27 \pm 0.23$ & $17.28 \pm 1.38$ & $\mathrm{~N}$ & $\mathrm{~N}$ & $2.8 \pm 0,2$ & $\mathrm{~N}$ \\
\hline
\end{tabular}

* N: negative; P: positive

We chose to present each parameter in independent sections in order to better present and discuss the results.

\section{Moisture}

The honey moisture content is an analysis of great importance due to this variables' influence on parameters such as taste, viscosity, and fluidity (BULIGNOL et al, 2016). In addition, the water excess may compromise the honey shelf-life, since the moisture content directly influences microorganism's water activity; besides, honey may undergo fermentation inside the package (VILHENA; ALMEIDA-MURADIAN, 1999; ARAÚJO et al., 2006). The fermentation process may occur due to yeast activity and, consequently, it makes the product unsuitable for consumption and trade (RIBEIRO et al, 2009). The moisture content in the samples used in the present study ranged from 6.62 to $24.6 \% \mathrm{~m} / \mathrm{v}$.

According to the current legislation, the maximum moisture content allowed in honey is $20 \% \mathrm{~m} / \mathrm{v}$ (MAPA, 2000) and 3 samples presented water content higher than that recommended in the legislation. However, as the acidity values were within the parameter set forth in the legislation, it is possible concluding that there were no indications of fermentative processes. High moisture levels could result from the lack of good manufacturing practices at some harvest stages, or it could indicate early harvesting, which might have happened when the honey could be "green" or unripe (RICHTER et al, 2011).

Ashes

It is possible determining some irregularities in honey processing such as lack of hygiene and absence of decantation and / or filtration at the end of the honey removal process performed by beekeepers (EVANGELISTARODRIGUES et al., 2005). The ashes express the mineral content in the food, as for honey, the differences may be related to floral source, environment, and to production and processing conditions (FELSNER, 2007; BULIGNOL et al, 2016). The 
maximum ash content allowed is $0.6 \mathrm{~g}$ for each $100 \mathrm{~g}$ of honey, but in case of molasse honey and of its mixtures with floral honey, up to $1.2 \mathrm{~g}$ of ash for each $100 \mathrm{~g}$ of honey can be tolerated (MAPA, 2000). Regarding the ashes determinations in the current study, it was verified that all the analyzed samples were within the recommendations in the legislation in force (MAPA, 2000).

$\mathrm{pH}$

Although the $\mathrm{pH}$ value does not appear as a mandatory analytical procedure for Brazilian honey quality control, this parameter is a useful auxiliary variable in quality evaluations (SOUZA; BAZLEN, 1998; SILVA, 2004). The honey $\mathrm{pH}$ value can be influenced by the nectar and soil $\mathrm{pHs}$ or by the association between vegetables contributing to honey composition (CRANE, 1985; MARCHINI et al, 2004). Honey $\mathrm{pH}$ is important because it influences the hydroxymethylfurfural formation rate (HMF) (SOUZA; BAZLEN, 1998). Accordingly, pH determination becomes an interesting quantification parameter due to the low analytical complexity it presents at the time to collect data about the acid content in the medium. In parallel it also contributes with complementary information when the idea is to find out whether the honey was subjected to high thermal amplitude or just to aging (CRANE, 1985; MARCHINI et al., 2004; BULIGNOL et al, 2016).

The mandibular substances found in bees are added to the nectar when they transport it to the hive, and this mixture may alter honey $\mathrm{pH}$ (EVANGELISTA-RODRIGUES et al., 2005). The pH influences honey texture, stability and shelf-life, because its values may indicate honey fermentation or adulteration caused by the bees themselves (TERRAB et al., 2004). All the samples in the current study presented acidic pH values ranging from 3.96 to 4.55 .

Acidity

Honey acidity may also derive from the presence of gluconic, succinic, malic, acetic, citric, formic, lactic, folic and butyric acids (PEREIRA, et al., 2003; RIBEIRO, 2009). The acidity origin in the honey results from organic acid variations, which are caused by different nectar sources, by the action of the enzyme glucose oxidase on the glucose giving origin to gluconic acid (TERRAB et al., 2004; EVANGELISTA-RODRIGUES et al., 2005). This enzyme keeps its action during storage, since it remains in activity even after honey processing (NOGUEIRA-NETO, 1997). In addition to nectar source, other factors, such as the production of acids by bacteria during maturation and the amount of minerals in the honey, influence its acidity (WHITE, 1989).

The organic acids in the honey represent less than $0.5 \%$ of the solids found in it, but they have a pronounced effect on flavor, because they are partially responsible for the high microbiological stability (PEREIRA, et al., 2003). The legislation allows maximum acidity $50 \mathrm{mEq} / \mathrm{kg}$ in honey (BRASIL, 2000); thus Table 2 shows that all the herein analyzed samples have recorded values within the legally recommended rates.

\section{Assessed Adulterants}

Lugol reaction

According to Wiese (2000), the application of iodine and potassium iodide (Lugol reactant) adulterates honey, which shows a characteristic color reaction due to the presence of starch and dextrin, because these components are not naturally found in pure honey. Starch addition is a fraud easy to be observed when producers intend to increase the 
content of solids in the honey (CAMARGO et al., 2003; BULIGNOL et al., 2016). Table 2 shows that the reaction to the Lugol agent was negative and that the analyzed batches were not adulterated by starch addition.

Fiehe reaction - a qualitative analysis applied to HMF

Hydroxymethylfurfural is used as quality indicator, since it results from the degradation of enzymes found in different honey types, although only small amounts of enzymes are found in mature honey. Small HMF amounts are found in freshly harvested honeys, but more significant values may indicate significant changes caused by longer storage at high room temperature and / or under overheating (VILHENA; ALMEIDA-MURADIAN, 1999), or by adulterations resulting from inverted sugar addition (SILVA et al., 2004; BULIGNOL et al., 2016). According to Bertoldi et al. (2004), honey adulterations can be carried out by using corn syrup, beet and also inverted syrup, because the inverted syrup is generated by the acid hydrolysis of corn syrup, which contains high hydroxymethylfurfural levels. In addition, the HMF content in honey can also be affected by acidity, $\mathrm{pH}$, water content and minerals (WHITE JÚNIOR, 1979).

The Fiehe reaction is a qualitative test that assesses HMF presence. The persistent red color indicates positivity for or strong HMF presence (possibly more than $200 \mathrm{mg} / \mathrm{kg}$ ) (LEAL et al., 2001). Just one of the herein analyzed samples presented positive result in this test.

Lund reaction

The Lund reaction indicates the presence of albuminoid substances, which are normal honey components precipitated by the tannic acid added to the sample. This precipitate forms a 0.6 to $3.0 \mathrm{~mL}$ deposit at the bottom of the test tube in presence of natural honey. However, the reaction does not occur in artificial honey; therefore, in the case of adulterated honey, the precipitate volume will be lower (BERTOLDI et al., 2004). All samples presented precipitate volume within the expected.

Dyestuff research

According to the current legislation (MAPA, 2000), honey color should not be changed due to the presence of sulfuric acid $(5 \% \mathrm{~m} / \mathrm{v})$ when the dye test is applied to the samples. The color change from honey to violet is an adulteration indicator (CODEX ALIMENTARIUS, 2001; ZENEBON et al, 2008). No color change was observed in any of the herein analyzed samples.

\section{Conclusion}

Based on the physicochemical parameters used to assess the quality of the honey from different locations in Rio Grande do Sul State, it is possible stating that they all complied with the legislation regarding the quality and food safety of the marketed products. In addition, it was not possible distinguishing the quality of the honey according to the inspection stamp chosen for each product since there was no difference between the quality of the honey using the municipal inspection stamp (SIM) and that of honey using the Coordination of Sanitary Inspection of Products of Animal Origin (Cispoa) inspection stamp or the Federal Inspection Service (SIF) stamp. Therefore, these results showed that according to the honey samples from the Southern Brazil production region, this agribusiness sector works with products of good applicability that meet the normative issues to assure the quality and safety of the produced and marketed honey. 


\section{Acknowledgments}

The authors are grateful to the Health Sciences Center of UNICRUZ for making the inputs available and the infrastructure to the study to be carried out.

\section{References}

AIDAR DS. Melioponíneos e ecossistema: importância da preservação das espécies (Hymenoptera, Apidae, Meliponinae). Inf. Ambiental Univ. Fed. Espírito Santo. 1997;(6):7.

ARAÚJO DR, SILVA RHD, SOUSA JS. Avaliação da qualidade físico-química do mel comercializado na cidade de Crato, CE. Rev. Biol. Ciênc. Terra. 2006;6(1):51-55.

AROUCHA EMM, OLIVEIRA A, NUNES G, MARACAJÁ PB, SANTOS M. Qualidade do mel de abelha produzido pelos incubados da IAGRAM e comercializado no município de Mossoró/RN. Revista Caatinga. 2008; 21(1): $211-217$.

AZEREDO LC, AZEREDO MAA, SOUZA SR, DUTRA VML. Protein contents and physicochemical properties in honey samples of Apis mellifera of different floral origins. Food Chemistry. 2003;80(2):249-254.

BERTOLDI FC, GONZAGA L, REIS VDA. Características físico-químicas do mel de abelhas africanizadas (Apis mellifera scutellata), com florada predominante de hortelã-do-campo (Hyptis crenata), produzido no Pantanal. In: Anais do Simpósio sobre Recursos Naturais e Socioeconômico do Pantanal [CD-ROM]; 2004 Novembro 23-26; Corumbá, Brasil.

BULIGON C, PEGORARO N, BERSCH P, SALAZAR RFS, SALAZAR LN. Avaliação de fraudes em méis consumidos na Região Noroeste do Rio Grande do Sul. Disciplinarum Scientia. Série Ciências da Saúde. 2016;16(2):213-220.

CAMARGO RCR, PEREIRA FM, LOPES MTR. Produção de mel. Embrapa Meio-Norte, versão virtual. 2003. [cited 2016 may 18]. Available from: https://sistemasdeproducao.cnptia.embrapa.br/FontesHTML/Mel/SPMel/index.htm.

CODEX ALIMENTARIUS. Revised Codex Standard for honey, Codex STAN 12-1981, Rev.(1987), Rev. 2 (2001). Council Directive 2001| 110| ES of 20 December 2001 relation to honey (Text). Official Journal of the European Communities.-2002.-L, v. 10, p. 47-52.

CRANE E. O livro do mel. São Paulo: Nobel. 1985. 226p

EVANGELISTA-RODRIGUES A, DA SILVA EMS, BESERRA EMF, RODRIGUES ML. Análise físico-química dos méis das abelhas Apis mellifera e Melipona scutellaris produzidos em regiões distintas no Estado da Paraíba. Ciência Rural. 2005;35(5):1166-1171.

FELSNER ML, CANO CB, BRUNS RE, WATANABE HM, ALMEIDA-MURADIAN LB, MATOS JR. Characterization of monofloral honeys by ash contents through a hierarchical design. Journal of Food Composition and Analysis. 2004;17(6):737-747.

JATI SR. Qualidade do mel de abelha, no estado de Roraima, Brasil. Ambiente: gestão e desenvolvimento, Boa Vista/RR. 2007;2(1):5-15.

LABORATÓRIO NACIONAL DE REFERÊNCIA ANIMAL - LANARA. Métodos físicos e químicos. In: LANARA editor. Métodos Analíticos Oficiais para o controle de produtos de origem animal e seus ingredientes; Brasília (Brasil), 1981. p.1-15.

LEAL VM, SILVA MH, JESUS NM. Aspecto físico-químico do mel de abelhas comercializado no município de Salvador-Bahia. Rev. Bras. Saúde Prod. An. 2001;1(1):14-18.

MARCHINI LC, SODRÉ GS, MORETI ACCC. Mel brasileiro: composição e normas. Ribeirão Preto: A. S. Pinto, 2004. 111 p.

MENDES CG, SILVA JBA, MESQUITA LX, MARACAJA PB. As análises de mel: Revisão. Revista Caatinga. 2009;22(2):07-14.

MINISTÉRIO DA AGRICULTURA, PECUÁRIA E ABASTECIMENTO - MAPA. Instrução Normativa No 11/2000 Regulamento Técnico de Identidade e Qualidade do Mel (Brasil): Ministério da Agricultura, Pecuária e Abastecimento; 2000. Diário Oficial [da] República Federativa do Brasil, Brasília, 23 jan. 2001. Seção 1, p. 18-23.

NOGUEIRA-NETO, P. Vida e criação de abelhas indígenas sem ferrão. São Paulo: Nougeirapis, 1997. 446p. 
NUNES TBA. Adulteração e influência do manejo na qualidade do mel. Enciclopédia Biosfera, Goiânia. 2005;(01):127.

PÉREZ RA, IGLESIAS MT, PUEYO E, GONZÁLEZ M, LORENZO C. Amino acid composition and antioxidant capacity of Spanish honeys. Journal of Agricultural and Food Chemistry. 2007;55(2):360-365.

PINTO JPDAN, RUDGE AC. Análise de mel comercializado no estado de São Paulo. Vet. zootec. 1991;(3):77-83.

REGO JGS, XIMENES RSS, CARNEIRO JGM. Qualidade de méis de Apis mellifera através de parâmetros físicoquímicos. In: Anais do V Encontro Sobre Abelhas [CD-ROM]; 2002 Outubro 21-24; Ribeirão Preto, Brasil. p. 284.

RIBEIRO RDOR, SILVA C, MONTEIRO ML, BAPTISTA RF, GUIMARÃES CF, MÁRSICO ET, MANO SB, PARDI HS. Avaliação comparativa da qualidade físico-química de méis inspecionados e clandestinos, comercializados no estado do Rio de Janeiro, Brasil. Rev. Bras. Ciênc. Vet. 2009;16(1):03-07.

RICHTER W, JANSEN C, LEMOS TS, MENDONÇA CRB, BORGES CD. Avaliação da qualidade físico-química do mel produzido na cidade de Pelotas/RS. Alim. Nutr., Araraquara. 2011;22(4):547-553.

RYBAK-CHMIELEWSKA H. Honey In: TOMASIK, P. Chemical and functional properties of food saccharides. Boca Raton: CRC, 2003. p.73-80.

SILVA CL, QUEIROZ AJM, FIGUEIREDO RMF. Caracterização físico-química de méis produzidos no Estado do Piauí para diferentes floradas. Revista Brasileira de Engenharia Agrícola e Ambiental. 2004;8(2-3):260-265.

SOCIEDADE BRASILEIRA DE FARMACOGNOSIA - SBF. Análise de Mel. Online. [cited 2016 jun 23]. Available from: http://www.sbfgnosia.org.br/Ensino/analise_mel.html

SOUZA DC, BAZLEN K. Análises preliminares de características físico-químicas de méis de Tiúba (Melipona compressipes) do Piauí. In: Anais do XII Congresso Brasileiro de Apicultura [CD-ROM]; 1998 Novembro 10-12; Salvador, Brasil. p. 267

TERRAB A, RECAMALES AF, HERNANZ D, HEREDIA FJ. Characterization of Spanish thyme honeys by their physicochemical characteristics and mineral contents. Food Chemistry. 2004;88(4):537-542.

VILHENA F, ALMEIDA-MURADIAN LB. Manual de análises físico-química do mel. 1.ed. São Paulo: APACAME, 1999. 16p.

WELKE JE, REGINATTO S, FERREIRA D, VICENZI R, SOARES JM. Caracterização físico-química de méis de Apis mellifera L. da região noroeste do Estado do Rio Grande do Sul. Ciência Rural. 2008;38(6):1737-1741.

WHITE JW. Methods for determining carbohydrates, hydroxymethylfurfural, and proline in honey: collaborative study. Journal-Association of Official Analytical Chemists. 1979;62(3):515-526.

WHITE JW. La miel. In: DADANT, H. (Editor) La colmena y la abeja melifera. Montevideo: Hemisfério Sul, 1989. p. 21-35.

WIESE H. Apicultura: Novos Tempos. 1 ed. Guaíba-RS: Editora Agropecuária LTDA. 2000. 424p.

ZENEBON O, PASCUET NS, TIGLEA P. Açúcares e produtos correlatos - Capítulo 7. In: ZENEBON, O.; PASCUET, N. S.; TIGLEA, P. Editors. Métodos físico-químicos para análise de alimentos. 5. ed. São Paulo: Instituto Adolfo Lutz; 2008. p. 23. 